\title{
RANCANGAN SOAL OPEN ENDED BERBASIS PEMBELAJARAN BLENDED LEARNING UNTUK MENINGKATKAN KEMAMPUAN BERPIKIR KREATIF MATEMATIS
}

\author{
Selvi Riwayati ${ }^{1}$, Lolik Atmajaya ${ }^{2}$, Masri $^{3}$ \\ 1,2,3 FKIP Universitas Muhammadiyah Bengkulu, Jl. Bali Kota Bengkulu, 38119 \\ riwayatselvi@gmail.com
}

\begin{abstract}
In the scale of traditional formal education, analytical thinking is prioritized compared to mathematical creative thinking. The existing problems only require students to find one solution to the problem, even though the acceleration of technological progress and limited natural resources require us to always think creatively and innovatively. Therefore, efforts are needed to foster students' mathematical creative thinking skills. One way is by giving open-ended questions combined with blended learning-based learning. Blended learning based learning is learning that combines traditional and modern learning by utilizing technology in the learning process. This research method is directed as a development research proposed by Tassmer which includes the preliminary stages, prototyping, and assessment. The population of this study were all students of the Mathematics Education Study Program FKIP UMB who took the Introductory Probability course, while the sample of this study was the second semester students. After going through the validation phase by a team of experts, this study produced teaching materials in the form of open-ended questions which were packaged in valid learning videos. Therefore, based on input and suggestions from the validator, the teaching material is worthy of being tested.
\end{abstract}

Keywords: Open Ended Questions, Blended Learning, Mathematical Creative Thinking Ability

\begin{abstract}
Abstrak
Dalam skala pendidikan formal tradisional, berpikir analisis lebih dikedepankan dibandingkan dengan berpikir kreatif matematis. Soal-soal yang ada hanya menuntut mahasiswa menemukan satu cara penyelesaian masalah, padahal percepatan kemajuan teknologi dan keterbatasan sumber daya alam menuntut kita untuk selalu berpikir secara kreatif dan inovatif. Oleh karena itu, diperlukan usaha untuk menumbuhkan kemampuan berpikir kreatif matematis mahasiswa. Salah satu cara yaitu dengan pemberian soal open ended yang dipadukan dengan pembelajaran berbasis blended learning. Pembelajaran berbasis blended learning merupakan pembelajaran yang menggabungkan pembelajaran tradisional dan modern dengan memanfaatkan teknologi dalam proses pembelajarannya. Metode penelitian ini diarahkan sebagai penelitian pengembangan yang dikemukan oleh Tassmer meliputi tahap preliminary, prototyping, dan assessment. Populasi dari penelitian ini adalah seluruh mahasiswa Prodi Pendidikan Matematika FKIP UMB yang mengambil mata kuliah Pengantar Probabilitas sedangkan sampel penelitian ini adalaha mahasiswa semester II. Setelah melalui tahapan validasi oleh tim ahli maka penelitian ini menghasilkan bahan ajar berupa soal open ended yang dikemas dalam video pembelajaran yang valid. Oleh karena itu, berdasarkan dari masukkan dan saran dari validator maka bahan ajar tersebut layak untuk diujicobakan.
\end{abstract}

Kata kunci: Soal Open Ended, Blended Learning, Kemampuan Berpikir Kreatif Matematis

\section{PENDAHULUAN}

Matematika seharusnya merupakan mata pelajaran yang menarik dan dapat mengembangkan kreativitas peserta didik. Namun kenyataan yang ada matematika bukan mata pelajaran yang disenangi bahkan cendrung dianggap pelajaran yang sulit. Pembelajaran matematika akan menjadi pembelajaran yang menyenangkan jika diajarkan dengan metode yang tepat dan peserta didik atau mahasiswa diberi kesempatan yang luas dalam mengemukakan gagasan baru sesuai dengan kemampuan mereka masing-masing. 
Rancangan Soal Open Ended Berbasis Pembelajaran Blended Learning untuk Meningkatkan Kemampuan Berpikir

Kenyataan yang terjadi di lapangan saat ini menunjukkan kondisi yang berbeda dengan situasi yang diharapkan. Tidak sedikit pendidik yang merasa kesulitan dalam membelajarkan peserta didik bagaimana menyelesaikan problem matematika. Padahal dalam proses penyelesaian suatu problem yang dikemukakan peserta didik merupakan tujuan utama dalam pembelajaran problem solving matematika. Hal ini senada dengan (Noer, 2011) pembelajaran yang ideal dimana masalah merupakan basis utamanya. Hal ini mengharuskan peserta didik memulai pembelajaran dengan memecahkan sebuah permasalahan. Masalah dimunculkan sedemikian rupa agar peserta didik mampu menginterprestasi masalah, mengupukan informasi dari permasalahan tersebut, mengevaluasi solusi alternatif serta menginterprestasikannya. Namun kenyataan di langangan sesuai dengan dikemukkan oleh (Fauzi et al., 2019) transfer pengetahuan atau proses pembelajaran yang dilakukan guru selama ini masih berorentasi pada penugasan materi pelajaran dan tidak memperhatikan makna atau nilai yang terkandung dalam pebelajaran tersebut.

Soal-soal yang diberikan umumnya mengharuskan peserta didik mencari satu jawaban yang benar. Dengan demikian pengembangan kemampuan mental-intelektual anak didik secara utuh diabaikan sehingga hasil belajar anak didik menjadi rendah. Sebagai contoh soal yang dikutip dari buku paket (Walpole Ronald E., 1992) sebagai berikut:

Berapa macam cara memilih 3 calon dari 8 pelamar yang berkualifikasi sama?

Dari soal di atas, peserta didik hanya diarahkan mencari satu jawaban yang benar. Soal tersebut merupakan soal tertutup yang mengarahakan satu solusi jawaban yang benar tanpa memberikan situmulus kepada peserta didik untuk menemukan sesuatu yang baru dalam penyelesaian masalah baik strategi, cara maupun pendekatan untuk sampai pada jawaban dari permasalahan di atas.

Berdasarkan hasil observasi di lapangan, pendidik telah berupaya melakukan berbagai usaha dengan menerapkan pembelajaran terstruktur dengan perencanaan tertentu untuk menyampaikan konsep-konsep matematika. Beragam metoda pembelajaran telah dikembangkan oleh para praktisi dan peneliti pendidikan dalam upaya mengatasi dan mengeliminasi masalah pendidikan yang terjadi di lapangan. Untuk melaksanakan pembelajaran matematika seperti di atas, diperlukan beberapa kecakapan dosen untuk memilih suatu pendekatan pembelajaran yang tepat, baik untuk materi ataupun situasi dan kondisi pembelajaran saat itu. Salah satu alternatif pendekatan pembelajaran yang dapat memenuhi prinsip-prinsip pembelajaran matematika tersebut yaitu pembelajaran open-ended dengan dipadukan model belended learning.

Menurut (Melianingsih Nuning, 2015) bahwa soal-soal open ended merupakan soal -soal yang tidak lengkap atau terbuka yang memberikan beranekaragam hasil jawaban sehingga memberikan pengalaman bagi peserta didik untuk menemukan sesuatu yang baru dalam penyelesaian masalah. Pemberian masalah tersebut bukan untuk menemukan jawaban tetapi mencari strategi, cara dan pendekatan untuk sampai pada jawaban dari masalah yang diberikan. Pemberian soal-soal open-ended dapat kolaborasikan dengan pembelajaran model blended learning. Dimana model blended learning ini mengkaloborasikan antara pembelajaran tatap muka (tradisional) dengan 
pembelajaran e-learning. Hal ini senada dengan (Sutisna, 2016) blended learning sebagai campuran kelas tradisional dan pembelajaran online yang tetap membuat nyaman tanpa menghilangkan makna kontak face to face. Pembelajaran e-learning sendiri merupakan bentuk pembelajaran yang memanfaatkan internet dalam proses pembelajarannya. Selain itu pemanfaatan internet tidak membatasi ruang dan waktu dalam pertukaran informasi antara dosen dan mahasiswa, mahasiswa dengan mahasiswa yang dapat berlangsung kapan dan dimana saja. Hal ini sejalan dengan (Hasbullah, 2014) bahwa kecenderungan pembelajaran matematika di masa depan mengubah pembelajaran tradisional ke arah pembelajaran masa depan, dimana belajar dapat dilakukan dimana saja, baik di ruang kelas, perpustakaan, di rumah, atau di jalan; kapan saja, tidak sesuai yang dijadwalkan. Tujuan penelitian ini untuk mengetahui apakah bahan ajar berbasis blended learning untuk meningkatkan kemampuan berpikir kreatif matematis yang dihasikan valid dan layak untuk digunakan.

Menurut Silver dalam (Noer, 2011) ada dua pandangan tentang kreativitas. Pandangan pertama disebut pandangan kreativitas jenius. Menurut pandangan ini tindakan kreatif dipandang sebagai ciri-ciri mental yang langka, yang dihasilkan oleh individu luar biasa berbakat melalui penggunaan proses pemikiran yang luar biasa, cepat, dan spontan. Pandangan kedua merupakan pandangan baru kreativitas yang muncul dari penelitian-penelitian terbaru-bertentangan dengan pandangan jenius. Pandangan ini menyatakan bahwa kreativitas berkaitan erat dengan pemahaman yang mendalam, fleksibel di dalam isi dan sikap, sehingga dapat dikaitkan dengan kerja dalam periode panjang yang disertai perenungan.

Torrance dalam (Fardah Dini Kinati, 2012) mendefinisikan secara umum kreativitas sebagai proses dalam memahami sebuah masalah, mencari solusi-solusi yang mungkin, menarik hipotesis, menguji dan mengevaluasi, serta mengkomunikasikan hasilnya kepada orang lain. Dipandang sebagai produk atau hasil Isaksen, Puccio, dan Treffinger (Fardah Dini Kinati, 2012) menggambarkan empat komponen kreativitas yang dapat diakses yaitu:

a. Kelancaran (fluency); kemampuan untuk menghasilkan sejumlah ide.

b. Keluwesan atau fleksibilitas (flexibility); kemampuan menghasilkan ide-ide beragam.

c. Kerincian atau elaborasi (elaboration); kemampuan mengembangkan, membumbui, atau mengeluarkan sebuah ide.

d. Orisinalitas (originality); kemampuan untuk menghasilkan ide yang tak biasa di antara kebanyakan atau jarang.

Menurut Krulik \& Rudnick (Siswono, 2011) mengungkapkan bahwa tingkat berpikir terdiri dari berpikir ingatan, dasar, kristis, dan kreatif. Dengan demikian indikator-indikator kemampuan berpikir kreatif yang ingin diungkap melalui instrumen yang diberikan meliputi kemampuan menghasilkan jawaban benar dengan banyak ide yang berkaitan (kelancaran), kemampuan memberikan cara penyelesaian alternatif yang lain dari yang biasa (fleksibilitas), dan kemampuan memperinci jawaban dengan jelas (elaborasi) yang dikemas dalam bentuk video pembelajaran. Video 
pembelajaran ini yang nantinya diintegrasikan dengan pembelajaran blended learning. Pada proses pembelajaran e-learning mahasiswa dituntut untuk dapat berperan aktif dan kreatif dalam memperoleh pengetahuannya sendiri untuk memperdalam pemahamannya terhadap materi. Materi tersebut dapat mahasiswa unduh kapan dan dimana saja, sementara dosen sebagai fasilitaor dapat menggugah materi atau tugas tambahan kapan saja. Hal ini di dukung oleh penelitian (Maryam, 2018) menemukan bahwa strategi blended learning berbantu microsof mathematic memberikan pengaruh yang signifikan terhadap kemampuan berpikir kreatif. Senada dengan hasil penelitian (Rochmad \& Ulinnuha, 2020) menyimpulkan bahwa pembelajaran blended learning dengan Gnomio efektif untuk meningkatkan kemampuan berpikir kreatif matematis siswa. Dengan demikian, berdasarkan beberapa hasil penelitian di atas dapat disimpulkan bahwa pembelajaran blended learning dapat meningkatkan kemampuan berpikir kreatif matematis mahasiswa.

Pada dasarnya istilah blended learning secara etimologi terdiri atas dua kata yaitu blended dan learning. Blended sendiri merupakan gabungan atau campuran untuk menghasilkan kualitas yang lebih baik. Sedangkan learning memiliki makna yaitu belajar. Dengan demikian blended learning merupakan gabungan metode tatap muka dan model daring atau online learning. Menurut Mosa, metode yang dikombinasikan terdiri 2 unsur utama, yaitu model pembelajaran tatap muka (class room lesson dengan metode online learning dalam (Darma et al., 2020) .

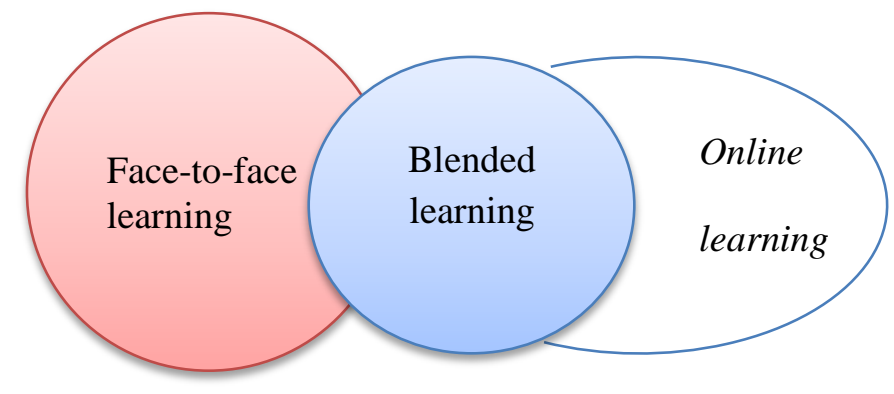

Gambar 1. Blended Learning dimodifikasi dari Mosa dalam (Darma, I K., dkk, 2020)

Dengan demikian pembelajaran blended learning menjadikan peserta didik belajar mandiri, kreatif, belajar menjadi efektif dan efisien.

\section{METODE}

Jenis penelitian ini yaitu Research and Development (R \& D). Penelitian ini merujuk pada model pengembangan Tessemer dalam (Wahyudi, 2016) meliputi preliminary (tahap persiapan dan perencanaan soal) dan tahap formative evaluation (tahap evaluasi dan revisi). Tahap formative evaluation pada gambar 2. 


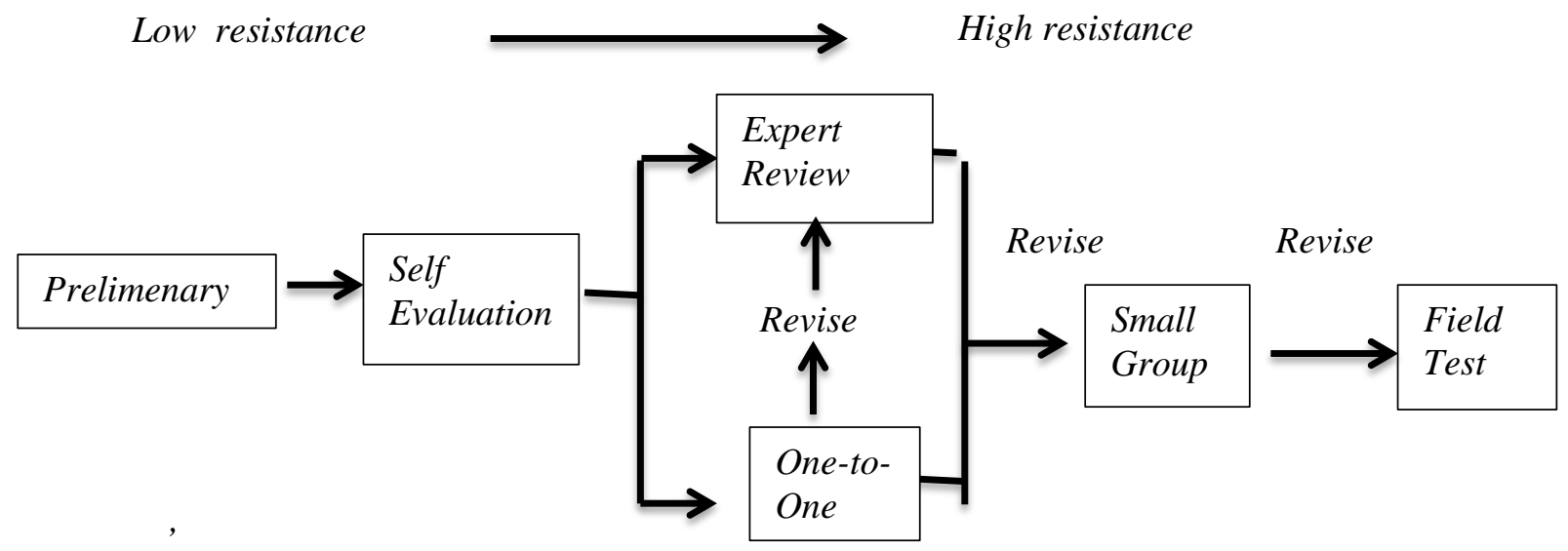

Gambar 2. Diagram Alir Formative Evaluation (Tessmer, 1993; Zukardi , 2006 )

Adapun subjek penelitian ini kelas A sebanyak 21 orang dan kelas B sebanyak 23 orang yang mengambil mata kuliah Pengantar Probabilitas. Sedangkan populasi dari penelitian ini adalah seluruh mahasiswa Prodi Pendidikan Matematika FKIP Universitas Muhammadiyah Bengkulu. Namun kondisi yang tidak memungkinkan dikarenakan adanya pandemi covid 19 maka penelitian ini baru sebatas expert review.

\section{HASIL}

\section{Analisis}

Pada tahap preliminary yaitu menganalisis materi yang dibahas pada semester genap sesuai dengan kurikulum yang berlaku di perguruan tinggi. Terdapat 9 bab yang dibahas dalam mata kuliah Pengantar Probabilitas yaitu materi tentang Ruang Sampel dan Kejadian, Konsep Probabilitas, Permutasi, Kombinasi, Konsep Probabilitas, Hukum Peluang, Peluang Bersyarat, Teorema Bayes, Distribusi Probabilitas, dan Diskrit Geometri. Setiap bab dicermati dan dipelajari melalui buku pelajaran yang digunakan mahasiswa. Hal yang dicermati adalah konteks permasalahan setiap hari yang dibahas disetiap bab. Berdasarkan hasil analisis, Permutasi dan Kombinasi memiliki potensi yang dikembangkan permasalahan open-ended, karena sangat banyak permasalahan kehidupan sehari-hari yang menerapkan konsep permutasi dan kombinasi. Berdasarkan analisis, materi Permutasi dan Kombinasi yang memungkinkan soal-soalnya yang menghasilkan banyak cara menjawab atau soal terbuka.

\section{Perancangan}

Pada tahap perancangan, peneliti menyusun dan merancang soal-soal open ended pada materi Permutasi dan Kombinasi yang dipadukan dengan video pembelajaran dikemas melalui pembelajaran blended learning.

\section{Self Evaluation}

Pada tahap ini peneliti menelah kembali soal dan video pembelajaran yang dibuat pada tahap perencanaan, hal ini bertujuan untuk mencari dan memperbaiki kesalahan atau kekurangan. 


\section{Expert Review}

Pada tahap ini dilakukan proses validasi prototype I dengan bantuan beberapa validator yang terdiri dari dosen pendidikan Matematika dan dosen TI untuk menganalisis soal-soal open ended dan video pembelajaran yang telah dikembangkan secara kualitatif. Adapun yang diperhatikan oleh validator adalah validitas kontraks, validitas isi, dan validitas bahasa. Proses validasi dilakukan dengan cara tatap muka langsung dan via email. Validasi melalui email dengan cara mengirimkan prototype I dan lembar validasi kepada validator, kemudian validator memberikan masukkan dalam bentuk komentar maupun catatan-catatan terhadap instrument penelitian yang dikirim. Sedangkan validasi tatap muka langsung dilakukan dengan cara terlebih dahulu mengirimkan prototype I melalui email, setelah validator mempelajari prototype I kemudian peneliti melalukan tatap muka langsung pada waktu yang sudah ditentukan. Pada saat pertemuan tersebut validator menilai langsung konten, konstruk, bahasa melalui komentar dan saran. Sementara untuk validasi video pembelajaran, validator menilai langsung pewarnaan, pemakaian kata dan bahasa, tampilan pada layar, penyajian dan animation dan suara. Hasil dari komentar dan saran validator, maka soal-soal protype I diperbaiki.

Tabel 1.

Perubahan sebelum dan sesudah revisi Soal-soal Open Ended

\begin{tabular}{|c|c|c|c|}
\hline No & Fokus Revisi & Sebelum Revisi & Sesudah Revisi \\
\hline 1 & $\begin{array}{l}\text { Revisi Kalimat } \\
\text { soal nomor } 1\end{array}$ & $\begin{array}{l}\text { Soal nomor } 1 \text { menggunakan kalimat } \\
\text { "Dalam sebuah showroom mobil } \\
\text { dipajang lima buah mobil sedan dengan } \\
\text { bentuk sama, hanya berbeda warna... }\end{array}$ & $\begin{array}{l}\text { Kalimat } \\
\text { menjadi Dalam sebuah } \\
\text { showroom } \\
\text { dipajang tiga buah } \\
\text { mobil sedan dengan } \\
\text { bentuk sama, hanya } \\
\text { berbeda warna. Pemilik } \\
\text { tidak mengharuskan } \\
\text { bahwa mobil warna } \\
\text { hitam diurutan } \\
\text { pertama, atau warna } \\
\text { putih maupun merah. }\end{array}$ \\
\hline 2 & $\begin{array}{l}\text { Pada soal no } 1 \\
\text { bagian a, b, c }\end{array}$ & $\begin{array}{l}\text { a. Apakah informasi-informasi } \\
\text { penting dari cerita di atas? } \\
\text { b. Konsep-konsep apakah yang } \\
\text { berkaitan dengan cerita di atas? } \\
\text { c. Menututmu berapa banyak carakah } \\
\text { pemilik showroom tersebut dapat } \\
\text { mengatur mobil-mobil tersebut? } \\
\text { Jelaskan jawabanmu. }\end{array}$ & $\begin{array}{l}\text { Soal butir a } \\
\text { dihilangkan, butir b } \\
\text { dan c diletakkan pada } \\
\text { indikator fleksibilitas }\end{array}$ \\
\hline
\end{tabular}

Untuk validasi video pembelajaran diperbaikki pada penyajian materi pembelajaran, hal ini dapat dilihat pada tabel 2. 
Tabel 2.

Perubahan sebelum dan Sesudah Revisi Video Pembelajaran

\begin{tabular}{|c|l|l|l|}
\hline Fokus Revisi & \multicolumn{2}{|c|}{ Sebelum Revisi } & \multicolumn{2}{c|}{ Sesudah revisi } \\
\hline Penyajian Materi & $\begin{array}{l}\text { 1. Penyajian materi tidak } \\
\text { komunikatif }\end{array}$ & $\begin{array}{l}\text { 1. Penyajian materi } \\
\text { komunikatif }\end{array}$ \\
& $\begin{array}{l}\text { 2. Penjelasan materi dalam video } \\
\text { pembelajaran } \\
\text { menstimulas anak untuk } \\
\text { berpikir kreatif }\end{array}$ & $\begin{array}{l}\text { 2. Penjelasan materi sudah mampu } \\
\text { menstimulan anak untuk berpikir } \\
\text { kreatif dengan pertanyaan- } \\
\text { pertanyaan yang diajukan }\end{array}$ \\
\hline
\end{tabular}

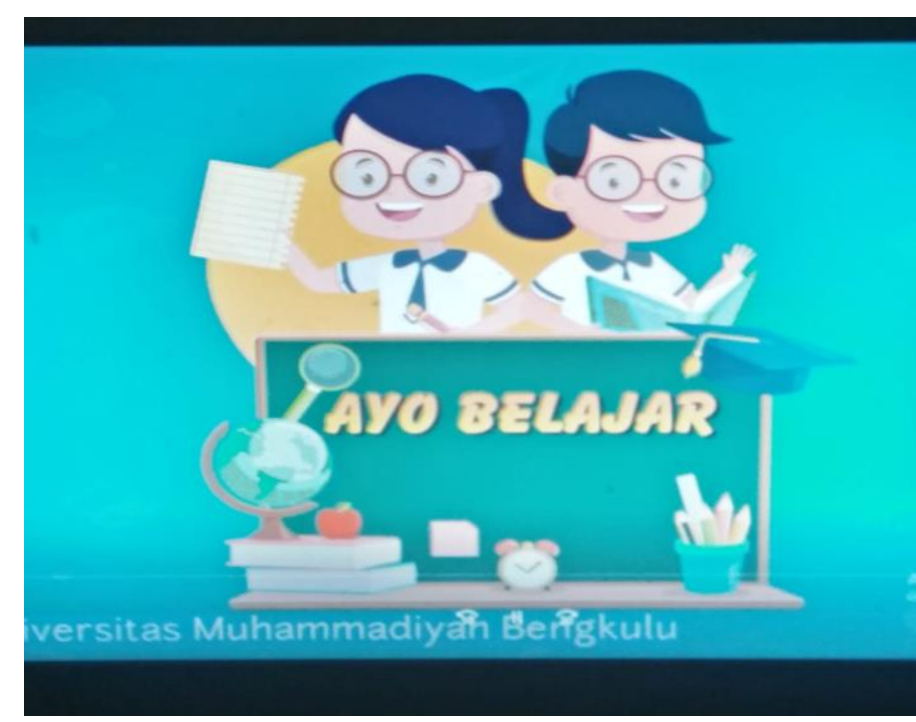

Gambar 2. Cover Video Pembelajaran tentang Materi Kombinasi

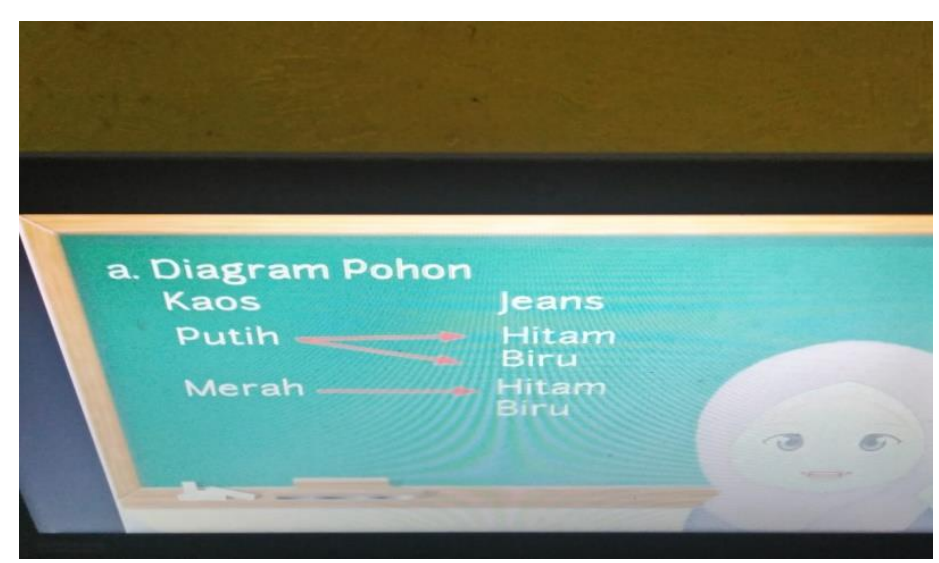

Gambar 3. Video Pembelajaran Materi Kombinasi

Pada gambar 2 merupakan tampilan depan dari video pembelajaran sedangakan gambar 3 memuat video pembelajaran dengan materi kombinasi . Video berisi materi dan soal-soal tersebut disisipkan di laman video pada google classroom. Pembelajaran online ini mengharuskan mahasiswa belajar secara mandiri rumah dengan melihat video pembelajaran tersebut. Dalam penggunaan 
Rancangan Soal Open Ended Berbasis Pembelajaran Blended Learning untuk Meningkatkan Kemampuan Berpikir Kreatif Matematis, Selvi Riwayati, Lolik Atmajaya, Masri

pembelajaran berbasis blended learning mahasiswa wajib memiliki username dan password sehingga tugas mahasiswa dapat dimonitor oleh dosen pengampu mata kuliah.

\section{Hasil Validasi produk oleh tim Ahli Materi dan Media Video Pembelajaran}

Hasil validasi soal-soal open ended berbasis blended learning untuk meningkatkan kemampuan berpikir kreatif matematis mahasiswa dijabarkan melalui penyajian dan analisis hasil validasi oleh ahli materi dan ahli media sebagai berikut:

Tabel 3.

Hasil Validasi Penilaian Ahli Media dan Materi

\begin{tabular}{cccc}
\hline No & Nama & Skor prosentase & Kriteria \\
\hline 1 & Ahli Materi & $85,5 \%$ & Baik \\
\hline 2 & Ahli Media & $83 \%$ & Baik \\
\hline
\end{tabular}

Pada Tabel 3 jelas dapat dilihat bahwa presentase dari keempat validator berada pada kreteria baik dengan persentase $85,5 \%$ dan $83 \%$, berada pada rentang $81 \%$ sampai dengan $100 \%$. Hal ini berarti produk blended learning layak digunakan dalam proses pembelajaran untuk meningkatkan kemampuan berpikir Kreatif matematis mahasiswa.

Penelitian ini menghasilkan 12 soal kemampuan berpikir kreatif yang terdiri dari 6 soal materi Permutasi dan 6 soal materi Kombinasi. Setiap butir soal memuat indikator kelancaran, keluwesan, dan kerincian hanya 2 soal yang memuat indikator kebaruan. Proses pengembangan melalui dua tahap, yaitu tahap preliminary dan formative evaluation yang terdiri dari self evaluation dan expert review. Untuk tahap one to one, small group, dan field test belum dilaksanakan mengingat kondisi belum kondusif. Untuk kedepannya akan dilaksanakan sampai tahap field test.

\section{KESIMPULAN}

Berdasarkan hasil penelitian awal prototype desain soal open ended yang dikemas dalam bentuk video pembelajaran berbasis blended learning untuk meningkatkan kemampuan berpikir kreatif matematis mahasiswa dapat disimpulkan bahwa penelitian ini menghasilkan soal open ended berbasis blended learning yang sesuai untuk pembelajaran di tingkat mahasiswa dengan model pengembangan Tessmer. Berdasarkan pengujian dari ahli media dan ahli materi menunjukkan bahwa soal open ended yang dikemas dalam bentuk video pembelajaran berbasis blended learning untuk meningkatkan kemampuan berpikir kreatif matematis mahasiswa layak digunakan dengan nilai dari ahli materi $85,5 \%$ dan ahli media $83 \%$.

Untuk tahap selanjutnya instrumen penelitian ini dapat dilaksanakan pada tahap one to one, small group dan field test. Hal ini bertujuan untuk melihat implementasi dari pengembangan soal-soal open ended yang dikemas dalam video pembelajaran berbasis blended learning mampu meningkatkan kemampuan berpikir kreatif mahasiswa. 


\section{DAFTAR PUSTAKA}

Darma, I. K., Karma, I. G. M., \& Santiana, I. M. A. (2020). Blended Learning, Inovasi Strategi Pembelajaran Matematika di Era Revolusi Industri 4.0 Bagi Pendidikan Tinggi. Prosiding Seminar Nasional Pendidikan Matematika, 3, 527-539.

Fardah Dini Kinati. (2012). Analisis Proses dan Kemampuan Berpikir Kreatif Siswa dalam Matematika Melalui Tugas Open-Ended. Kreano: Jurnal Matematika Kreatif-Inovatif, 3(1), 1-9.

Fauzi, A., Waluya, B., \& Masrukan. (2019). Pembelajaran matematika dengan pendekatan realistic mathematics education( RME ) berbasis soal open-ended untuk meningkatkan komunikasi. Phenomenon, 09(1), 87-98.

Hasbullah, H. (2014). Blended Learning, Trend Strategi Pembelajaran Matematika Masa Depan. Formatif: Jurnal Ilmiah Pendidikan MIPA, 4(1), 65-70. https://doi.org/10.30998/formatif.v4i1.140

Maryam, I. (2018). Pengaruh Blended Learning Berbantuan Microsoft Mathematic Terhadap Kemampuan Berpikir Kreatif. Jurnal Pendidikan Surya Edukasi (JPSE), 4(2), 23-34. http://ejournal.umpwr.ac.id/index.php/surya/article/view/5340

Melianingsih Nuning, S. (2015). Keefektifan Pendekatan Open Ended dan Problem Solving pada Pembelajaran Bangun Ruang Sisi Datar di SMP. Jurnal Riset Pendidikan MatematikaJ, 2(2), 113.

Noer, S. H. (2011). Kemampuan Berpikir Kreatif Matematis Dan Pembelajaran Matematika Berbasis Masalah Open-Ended. Jurnal Pendidikan Matematika, 5(1). https://doi.org/10.22342/jpm.5.1.824.

Rochmad, R., \& Ulinnuha, R. (2020). Blended learning Menggunakan Gnomio untuk Meningkatkan Kemampuan Berpikir Kreatif Matematis Siswa SMP. PRISMA, Prosiding Seminar Nasional Matematika, 3, 476-481. https://journal.unnes.ac.id/sju/index.php/prisma/article/view/37647

Siswono, T. Y. E. (2011). Level of student's creative thinking in classroom mathematics. Educational Research and Reviews, 6(7), 548-553.

Sutisna, A. (2016). Pengembangan Model Pembelajaran Blended Learning pada Pendidikan Kesetaraan Program Paket C dalam Meningkatkan Kemandirian Belajar. JTP - Jurnal Teknologi Pendidikan, 18(3), 156-168. https://doi.org/10.21009/jtp1803.2

Wahyudi, T. (2016). Pengembangan Soal Penalaran Tipe TIMSS Menggunakan Konteks Budaya Lampung. Jurnal Didaktik Matematika, 3(1), 1-14.

Walpole Ronald E. (1992). Pengantar Statistik Edisi ke-3 (B. Sumantri (ed.); 3rd ed.). Gramedia Pustaka Utama. 